\title{
Brownfields to green fields: realising wider benefits from practical contaminant phytomanagement strategies
}

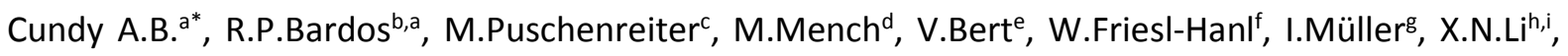
N.Weyens ${ }^{j}$, N.Witters ${ }^{j}$, and J.Vangronsveld ${ }^{j}$

a School of Environment and Technology, University of Brighton, Brighton, UK

${ }^{b}$ r3 Environmental Technology Ltd., Reading, UK

c University of Natural Resources and Life Sciences (BOKU), A-3430 Tulln, Austria

d BIOGECO, INRA, Univ. Bordeaux, 33615 Pessac, France

e INERIS, Clean and Sustainable Technologies and Processes Unit, DRC/RISK, Parc Technologique Alata, BP2, 60550 Verneuil en Halatte, France

${ }^{f}$ AIT Austrian Institute of Technology - GmbH, Health \& Environment Department, 3430 Tulln, Austria

g Saxon State Office for Environment, Agriculture and Geology, D-01109 Dresden, Germany

${ }^{h}$ State Key Laboratory of Urban and Regional Ecology, Research Center for Eco-Environmental Sciences (RCEES), Chinese Academy of Sciences, Beijing 100085

' Graduate University of Chinese Academy of Sciences, Beijing 100049, PR China

j Centre for Environmental Sciences (CMK), Hasselt University, 3590 Diepenbeek, Belgium

* Corresponding author: Tel: +44 (0)1273 642288; Email: A.Cundy@brighton.ac.uk.

Present address: School of Ocean and Earth Science, National Oceanography Centre (Southampton), Southampton, SO14 3ZH, UK. Email: A.Cundy@soton.ac.uk

Published in Journal of Environmental Management, Sustainable Remediation Special Issue. 


\section{Abstract.}

Gentle remediation options (GROs) are risk management strategies or technologies involving plant (phyto-), fungi (myco-), and/or bacteria-based methods that result in a net gain (or at least no gross reduction) in soil function as well as effective risk management. GRO strategies can be customised along contaminant linkages, and can generate a range of wider economic, environmental and societal benefits in contaminated land management (and in brownfields management more widely). The application of GROs as practical on-site remedial solutions is still limited however, particularly in Europe and at trace element (typically metal and metalloid) contaminated sites. This paper discusses challenges to the practical adoption of GROs in contaminated land management, and outlines the decision support tools and best practice guidance developed in the European Commission FP7funded GREENLAND project aimed at overcoming these challenges. The GREENLAND guidance promotes a refocus from phytoremediation to wider GROs- or phyto-management based approaches which place realisation of wider benefits at the core of site design, and where gentle remediation technologies can be applied as part of integrated, mixed, site risk management solutions or as part of "holding strategies" for vacant sites. The combination of GROs with renewables, both in terms of biomass generation but also with green technologies such as wind and solar power, can provide a range of economic and other benefits and can potentially support the return of low-level contaminated sites to productive usage, while combining GROs with urban design and landscape architecture, and integrating GRO strategies with sustainable urban drainage systems and community gardens/parkland (particularly for health and leisure benefits), has large potential for triggering GRO application and in realising wider benefits in urban and suburban systems. Quantifying these wider benefits and value (above standard economic returns) will be important in leveraging funding for GRO application and soft site end-use more widely at vacant or underutilized sites. 


\section{Introduction.}

Large areas of land around the world have been impacted by former industrial and other anthropogenic activities. These include urban brownfield sites, former mining or resource extraction sites, and urban and rural areas affected by diffuse contamination. For example, there are estimated to be close to one million (or more) potential brownfield sites across the European Union (Oliver et al., 2005), a considerable fraction of which may have real or perceived contamination problems (Panagos et al., 2013). The German register of contaminated sites lists about 300,000 potentially contaminated sites (UBA 2015), while the French Basol database references 6319 polluted sites requiring government action, mainly located in Rhone-Alpes (17\%), Nord-Pas-de-Calais (10.5\%), Aquitaine (9\%) and Ile de France (8.6\%) (Commissariat Général au Développement Durable 2013; Basol 2016). Although the extent of diffuse contamination is less well-known thousands of square kilometres of land are potentially affected (Bardos et al., 2011). In Belgium and the Netherlands alone, two moderate-sized countries which share a similar history of industrial development and subsequent partial industrial decline with much of western Europe, diffuse contamination by metals affects approximately $700 \mathrm{~km}^{2}$ of land (Witters et al., 2009). While a number of impacted sites have been remediated or restored to productive use a significant land area remains derelict or underutilized because its restoration is uneconomic or unsustainable using conventional methods. This dereliction and underutilization is a particular problem for large land areas where contamination may be causing concern but is not present at highly elevated levels (such as areas impacted by diffuse metal smelter contamination), or where smaller sites are economically marginal for hard redevelopment (e.g. where economic returns from site redevelopment for housing are insufficient to cover conventional remediation or rehabilitation costs). An expanding body of work since the 1990s however indicates that management and re-utilisation of these sites is possible through use of low input longer term remediation approaches (e.g. ITRC, 2009), particularly through so-called gentle remediation options (GROs) (Mench et al., 2010; Kidd et al., 2015).

GROs have been defined as risk management strategies or technologies that result in a net gain (or at least no gross reduction) in soil function as well as achieving effective risk management (Cundy et al., 2013). They encompass many technologies, including the use of plant (phyto-), fungi (myco-), and/or bacteria-based methods, with or without chemical additives or soil amendments, for reducing contaminant transfer to local receptors by extraction, transformation, or degradation of contaminants, or by in-situ stabilization (using biological and/or chemical processes). Plant (phyto)based GROs are described in Table 1. As the treated soil remains unsealed, GROs are highly applicable to soft-end use for a site, e.g. for urban or community park-land, biomass generation etc. (Mench et al., 2009; Fässler et al., 2010; Bert et al., 2012a; Evangelou et al., 2012; 2015; HOMBRE 2013; Kidd et al., 2015; Marchand et al., 2015; Robinson et al., 2015). Furthermore, depending on the specific site situation GROs can have significantly lower deployment costs than conventional remediation technologies (Vangronsveld et al., 2009; Kuppusamy et al., 2016 ${ }^{\mathrm{a}, \mathrm{b}}$ ). GROs can also contribute strongly to sustainable remediation strategies, by providing a broad range of wider economic, social and environmental benefits (e.g. economic returns through biomass production; restoration of plant, microbial, and animal communities; water filtration and run-off and drainage management; amenity and recreation (Vangronsveld et al., 1995ª, 2009; Witters et al., 2012; Cundy et al., 2013; 2015)). 
Despite these benefits the application of GROs as practical on-site remediation strategies is still limited, particularly in Europe and for trace element (typically metal and metalloid) contaminated sites (Vangronsveld et al., 2009; Mench et al., 2010). This is due to a number of perceived (or actual) barriers or impediments related to technical issues and stakeholder perceptions, and which are further discussed in section 2. In order to overcome some of the barriers to practical application of GROs within Europe, the 17 partner GREENLAND (Gentle Remediation of Trace Element Contaminated Land) project was initiated in $\mathbf{2 0 1 0}$ (with funding from the European Commission FP7 Programme). This project involved a network of academic institutes, regulators and industry bodies, and practical field applications of GROs, and has developed practical case studies, assessment and decision support tools and practical guidance for the application of GROs at sites contaminated with metals and metalloids.

This paper reviews emerging ideas about the use of GROs in achieving effective risk management along contaminant linkages, and the wider benefits that GROs have to offer contaminated land (and brownfield) restoration, for soft reuses in particular. It discusses challenges to the practical adoption of GROs in contaminated land management, and summarises the decision support tools and best practice guidance developed in the GREENLAND project aimed at overcoming these challenges. The wider possibilities for implementation of GROs as practical contaminated site management strategies, particularly for metal and metalloid contaminated sites, and their potential role in sustainable site management strategies are also discussed, in particular how GROs can be applied to "leverage" wider economic, environmental and societal benefits at contaminated sites.

\section{Challenges to the adoption of GROs in contaminated land management.}

The main barriers to widespread GROs application, in Europe and more widely, derive from a general focus of the remediation sector on remediation for critical risks or to rapidly return smaller urban brownfield sites to productive use (Cundy et al., 2013). This focus has tended to exclude GROs, which are perceived as slow and more suited to large area problems (Puschenreiter et al., 2009). A lack of convincing pilot applications, and legal frameworks which predicate removal or destruction of contaminants to reach generic soil concentration targets, also pose significant barriers (Puschenreiter et al., 2009; Vangronsveld et al., 2009; Cundy et al., 2013). Stakeholders (site owners, planners, consultants, regulators, local community, investors, insurers etc) may also lack awareness of and/or confidence in the application of GROs (Onwubuya et al., 2009). In particular:

- There is uncertainty relating to the required time-scales for GROs, and their long-term effectiveness as risk management methods (e.g. Puschenreiter et al., 2009).

- (Within Europe at least) GROs services are offered by relatively few consultants and contractors, which has limited their availability (Cundy et al., 2013).

- There is limited awareness of the role of GROs as practical site solutions.

A questionnaire-based survey of stakeholder perceptions of GROs, carried out in the EU SUMATECS (Sustainable management of trace element contaminated soils) project in 2008, assessed reasons for hindrance in the wider uptake of gentle remediation options (Puschenreiter et al., 2009). The 130 participants of the survey were drawn from more than 10 European countries, and included representatives from university/research institutions, regional authority/government, 
environmental consultancies, remediation contractors, and other key stakeholder groups (including land owners, investors, and pressure groups). While gentle remediation technologies were known to most respondents ( $87 \%$ of respondents) they were rarely applied, with perceived disadvantages in the need for long-term monitoring and a lack of applicability for some types of sites and contaminants. Lack of knowledge, experience and convincing pilot projects were considered the main obstacles for more general application of gentle remediation technologies. Kennen and Kirkwood (2015) note similar obstacles, and discuss further (historical) issues whereby a huge surge of interest in phytotechnologies in the 1990s was followed by mixed performances in the field (due to application at unsuitable sites, or that implementation occurred before the supporting science was substantiated), causing a crash in stakeholder confidence in GROs which is only slowly being recovered.

\section{The GREENLAND project - overcoming the impediments to practical application.}

The GREENLAND project has adopted a transparent and simple plan of action to address these impediments. It has co-ordinated data collection from a range of long-duration GRO pilot projects at contaminated sites across Europe, evaluated standard protocols and methods for site monitoring, and developed a set of specific design aids (for use when GRO appear to be a viable option) to promote the appropriate use of gentle remediation options and encourage participation of (and inform) stakeholders. The specific aims of the project were to:

1. Assess the efficiency of GRO via long-term ( $>5$ year duration) field trials;

2. Test the possibilities for biomass valorisation at trace element contaminated sites;

3. Evaluate a set of soil tests to assess GRO performance or "success";

4. Enhance the efficiency of GRO (e.g. by selection of the most effective plants, microbes, and soil amendments, and by improving agronomic practices);

5. Develop a decision support system, stakeholder engagement guidance, and a guide for practical application of GRO.

The project made use of existing long-term (greater than 5 years) GRO field experiments in Europe (Belgium, France, Sweden, Switzerland, Poland, Austria, Germany, and Spain, Table 2, http://www.greenland-project.eu/), coupled with laboratory and industrial trials, stakeholder discussions, and desk reviews. These were used to provide: operational data on the effectiveness of GRO under different contaminant and site scenarios; pilot case studies/applications for different GRO types; high-level GRO technical applicability guides; assessment and decision support tools (including an economic cost calculator tool); and technical guidance to support the design, implementation and assessment / monitoring of GRO strategies on a site specific level.

Two key outputs from the project were (1) a (multi-lingual) best practice guidance, designed to encourage wider consideration and use of GROs as part of effective risk management strategies within Europe and in other geographic regions, and (2) a practical decision support tool (DST), presented as a simple MS-Excel based workbook and designed to support stakeholder engagement, site options appraisal and decision making. Both outputs are available for download from the GREENLAND project website (www.greenland-project.eu). The overall structure and content of the DST have already been described by Cundy et al., (2015). This paper focuses on aspects of the best 
practice guidance and DST (and the GREENLAND project more widely) which develop ideas around the use of GROs in achieving effective risk management along contaminant linkages, and which assess economic, social and environmental benefits of GRO application (i.e. wider benefits related to sustainable remediation principles and concepts). We also discuss emerging ideas around a shift in practice from phytoremediation to phytomanagement approaches, in which a long term combination of profitable site use with gentle remediation options (GRO) leads gradually to the reduction of pollutant linkages and the restoration or generation of wider site services.

\section{Customising GROs along contaminant linkages, and wider GRO-based site management strategies.}

Gentle remediation options, specifically those using plants and their associated soil microbial systems, can be applied to remove the labile (or bioavailable) pool of inorganic contaminants from a site (phytoextraction), remove or degrade organic contaminants (e.g., phytodegradation), protect water resources (e.g., rhizofiltration), or stabilize or immobilize contaminants in the subsurface (e.g., phytostabilization, in-situ immobilization/phytoexclusion) (e.g., Vangronsveld et al., 2009; Mench et al., 2010; Cundy et al., 2015, Table 1). A number of studies have shown the potential of GROs to provide rapid risk management via pathway control coupled with a longer term removal or immobilization/isolation of contaminants (e.g., Bert et al., 2009, 2012a; Friesl-Hanl et al., 2009; Kolbas et al., 2011; Cundy et al., 2013; Herzig et al., 2014; Kennen and Kirkwood., 2015; Janssen 2015). For example, within the GREENLAND network of sites (Table 2):

Phytoextraction (using tobacco variants and sunflower mutants selected for their metal tolerance and phytoextraction properties) was applied to Zn-contaminated soils at a former hot dip Zn factory at Bettwiesen in eastern Switzerland. The overall results of a 5-year time series experiment showed a lowering of the labile $\mathrm{Zn}$ pool in the soils by $45-70 \%$, indicating the feasibility of bioavailable zinc stripping at the site within a few years (Herzig et al, 2014). In the northeast of Belgium (the Campine region), an area of more than $280 \mathrm{~km}^{2}$ is historically contaminated with mainly $\mathrm{Cd}, \mathrm{Zn}$ and $\mathrm{Pb}$. Biomass production and metal accumulation of pre-selected tobacco clones (Nicotiana tabacum L.), pre-selected sunflower mutants (Helianthus annuus L.) and a commercial hemp (Cannabis sativa L.) were determined over 2-4 years while the phytoextraction potentials of more than 200 different commercially available and experimental (designed by the Institute of Nature and Forest Research, INBO) poplar (Populus) and willow (Salix) clones in short rotation coppice (SRC) were assessed at the end of the first cutting cycle (after 4 growing seasons). The tobacco clones and the sunflower mutants were shown to be efficient extractors of $\mathrm{Cd}$ and $\mathrm{Zn}$ respectively, while the highest simultaneous extraction of $\mathrm{Cd}$ and $\mathrm{Zn}$ was observed using woody species in SRC. Phytoextraction of $\mathrm{Pb}$ was limited using the crops tested but this was not considered to be a major problem given the low bioavailability and activity of $\mathrm{Pb}$ at the site. The estimated long remediation times ( $>60$ years to reduce total $\mathrm{Cd}$ contents to Flemish guideline values) however indicated that, in this case, additional value generated from economic and (other) environmental benefits will be crucial for large-scale implementation of metal phytoextraction (Janssen 2015).

In France, aided phytostabilisation was applied over a 6 year period on a 1 ha site used for on-land disposal of $\mathrm{Zn}, \mathrm{Pb}$ and $\mathrm{Cd}$ contaminated sediments at Fresnes-sur-Escaut in northern France. 
Following initial site clearance (mainly of the invasive plant Japanese knotweed), a basic mineral amendment (Optiscor ${ }^{\mathrm{TM}}$ ) was applied to the soil, which was then planted at high density with a commercial cultivar of grass (Deschampsia cespitosa) (Bert et al., 2009, 2012b). The trial showed stabilisation of contaminants with effectively $100 \%$ vegetation cover (reducing soil - human contaminant linkages via direct soil exposure and dust inhalation) and a reduction in plant-metal uptake and transfer (foliar element concentration in cover grass was reduced by $60 \%$ (for $\mathrm{Zn}$ ) and $20 \%$ (for Cd)). Metal values in plant biomass were sufficiently low to allow subsequent biomass use as compost.

In Austria, in-situ immobilisation / phytoexclusion was applied over a 13 year period at Arnoldstein (south Austria) on arable land impacted by $\mathrm{Pb} / \mathrm{Zn}$ smelter emissions. Gravel sludge and iron bearing materials (red mud, $3 \%(\mathrm{w} / \mathrm{w})=9 \mathrm{~kg} / \mathrm{m}^{2}=90 \mathrm{t} / \mathrm{ha}$ ) were applied as soil amendments and $\mathrm{Cd}$ excluding cultivars of commercial food crops (barley, maize, and potatoes) grown, with the aim of reducing contaminant transfer from soil to plants and groundwater (Friesl-Hanl et al., 2009). Amendment addition generated a significant reduction in the labile contaminant pool in the soils ( $\mathrm{Cd}$ could be reduced by $>80 \%$; $\mathrm{Zn}>90 \%$ and $\mathrm{Pb}>90 \%$ ), while $\mathrm{Cd}$ uptake into barley could be reduced by $>75 \%$ (compared to an accumulating cultivar). Uptake into maize silage was reduced by up to $50 \%$ for $\mathrm{Cd}, 60 \%$ for $\mathrm{Pb}$, and $70 \%$ for $\mathrm{Zn}$.

Site risk management by GROs can be summarised in an approach which customises or tailors GROs along contaminant linkages to manage site risk (Figure 1), discussed previously in Cundy et al., (2013). Here, methods such as phytoextraction can be used to remove the bioavailable contaminant pool at a site, or methods such as in-situ stabilisation immobilise the contaminants within the soil, and so reduce the mass flux of contaminants to the receptor. Pathway management can also be applied through rhizofiltration or phytovolatilisation options, which reduce contaminant transfer to groundwater and surrounding water bodies, while plants (as ground cover) can be used to manage receptor access to the subsurface. Application of soil amendments (such as lime, red mud, zeolites, cyclonic ashes, iron grits and slags, or composts, biochar and other organic amendments) can reduce the bioavailability of a wide range of contaminants while simultaneously enhancing revegetation success and, thereby, protect against offsite movement of contaminants by wind and water (Vangronsveld et al., 1995a,b,, 2009; Bes and Mench 2008; Kumpiene et al., 2008; Puschenreiter et al., 2009; Bolan et al., 2014; Jones et al., 2016). Building further on this contaminant linkages approach, the design and implementation guidance from the GREENLAND project focuses on the concept of phytomanagement (i.e. the long term combination of profitable site use with GROs which leads gradually to the reduction of contaminant linkages and the restoration of ecosystem and other site services), rather than phytoremediation per se. The latter has been often associated in the contaminated land sector with phytoextraction, which is perhaps the most well-known GRO, and which has been widely tested at demonstration scale (e.g. Vangronsveld et al., 2009; Mench et al., 2010). Phytoextraction has generally been seen as a source management strategy which aims to gradually remove trace elements from soil over time into above-ground biomass. It has poor acceptance as an effective source management tool amongst many contaminated land practitioners as contaminant removal may take decades, source removal effectiveness depends strongly on contaminant bioavailability, early phytoextraction-based site trials met with mixed success, and there may be concerns over presence of contaminants in harvested biomass (e.g. Van Slycken et al., 2013a,b; Cundy et al., 2013; Delplanque et al., 2013; Cao et al., 2015; Janssen 2015; Kennen and Kirkwood, 2015). Phytomanagement refers to a wider design and management strategy which, 
alongside risk management, places realisation of wider (including economic) benefits at the core of site design, and uses GRO as part of integrated site management strategies rather than applying plant monocultures over extensive areas to gradually extract the bioavailable contaminant pool (although this latter approach still has clear merits under some site circumstances, e.g. Herzig et al., 2014). Phytomanagement approaches allow the use of plant-based systems as a "holding strategy" (i.e. reducing contaminant transfer and site risk on vacant sites, while providing other benefits such as biomass generation, amenity and leisure, site value uplift of surroundings, urban climate management, ecosystem services etc., prior to development of favourable economic conditions for hard redevelopment or other site regeneration), or as part of a zoned, mixed site use, approach where GRO are applied (in combination with "hard" cover systems or conventional remediation technologies) on less contaminated areas within a site, which may better reflect site (and contaminant) heterogeneity (Neu and Müller 2014). The large potential for GRO incorporation into urban design and landscape architecture via wetlands, riparian buffers, stabilisation mats, air flow buffers, stormwater filters, interception hedgerows etc., has been extensively discussed in Kennen and Kirkwood (2015), while a number of European examples exist which show the potential for use of GRO in site "greening" and for realisation of wider site benefits as part of general site regeneration strategies (e.g. www.thelandtrust.org.uk). GRO design and successful application will however be strongly site and contaminant specific: e.g. for phytoextraction to be successful, metal(loid)s must be present in chemical forms/solubilities which plants can absorb and translocate to shoots. Conversely, phytostabilization requires that these metal(loid)s can be either converted to unavailable forms for plant uptake and remain retained in the soil matrix preventing leaching losses, or captured and retained in the root systems. Given this site and contaminant specificity, it is always recommended to implement and monitor field trials after the selection of feasible GRO before deploying the selected GRO at full implementation scale. The best conventional remediation option should also be compared in parallel to have an alternative in case of GRO failure or underperformance. GRO application may also require additional technical input from agronomists and plant specialists, institutional or planning controls to avoid shifts in land-use or land management, and a supportive local/regional regulatory framework (in cases where contaminants are stabilised in the ground, rather than removed (e.g. phytostabilization, in-situ immobilization/phytoexclusion) or where only the bioavailable contaminant fraction is removed (e.g. in phytoextraction)).

The GREENLAND best practice guidance and DST summarise conceptual site models and supporting data for a series of longer-term trial sites drawn from the GREENLAND network, which have shown effective risk management for different metal(loid) contaminants under contrasting site conditions. Such pilot-scale applications of effective GRO strategies (i.e. "success stories") are key in providing robust technical and practical data for GRO implementation and in engendering confidence in stakeholders, both in terms of illustrating the long-term risk management potential of GRO but also in showing how wider economic, environmental and societal benefits can be realised. Pilot sites can also be pivotal in education and training as demonstrator sites, both for specialists (e.g. regulators, contaminated land consultants) and non-specialists. For example, the BIOGECO phytoremediation platform is a large Cu-contaminated wood preservation site located in the Gironde, SW France (and part of the GREENLAND site network) which has been used as a pilot site since 2006 for phytostabilisation, aided phytostabilisation (combining in situ stabilisation and phytostabilisation), (aided) phytoextraction, and PAH phytodegradation. The platform provides site training in 
phytoremediation and risk assessment (and related topics) to University students and engineers, and is supported by the Agence de l'Environnement et de la Maîtrise de l'Energie (ADEME) to act as a demonstrator site to train consultants and other stakeholders in effective GRO application. Other French pilot sites are included in the SAFIR network supported by ADEME (http://www.safirnetwork.com/)

\section{Realisation of wider benefits.}

A diverse range of wider benefits can be realised when applying phyto- and other GRO -based risk management strategies. For example, application of phytoremediation or use of soil amendments (as part of, or independently of, in-situ immobilisation and phytostabilisation applications) may generate "core" benefits or services in the form of risk mitigation of contaminated land and groundwater, but also other benefits such as soil improvement, water resource improvement, provision of green space, renewable energy and material generation, greenhouse gas mitigation, and amenity and economic assets. Table 3 draws on data from the GREENLAND project, and from the EU FP7 HOMBRE project (www.zerobrownfields.eu) to classify these wider benefits and give specific examples, drawn from field and pilot trial GRO sites, where these benefits have been evidenced. Examples are shown from sites contaminated with metal(loid)s or with other contaminants of concern. Many individual sites show multiple benefits. For example, the Betteshanger site is a former coal-mining site located in East Kent, southeast U.K., which was regenerated between 2002 and 2011 with financial support from UK national government (BBP Regeneration, 2008). Gentle remediation strategies applied at Betteshanger involved landscaping and green cover, and the construction of a Sustainable Urban Drainage System (SUDS) which incorporated reed beds for treatment of surface run-off and foul water from new and existing built developments. In addition to risk management and water resource protection benefits, the regenerated site provides economic and amenity assets, and enhances the local environment: the major Fowlmead Country Park on its former waste tip site includes provision for walking, cycling, horse-riding and wildlife observation, while the smaller former coal-mine site accommodates a local park and up to $35,000 \mathrm{~m}^{2}$ of warehousing, industrial and office space (BBP Regeneration, 2008, Cundy et al., 2013). In Belgium, research at the Lommel site in the Campine region has targeted the repurposing of $\mathrm{Cd}$ and $\mathrm{Zn}$ contaminated agricultural land for biomass and energy crops (using silage maize (Zea mays), rapeseed (Brassica napus), willow (Salix spp.) and poplar (Populus spp.), the latter two in short rotation coppice systems), rather than food crops (Meers et al., 2010; Ruttens et al., 2011; Witters et al., 2012, reviewed also in Kennen and Kirkwood, 2015). The soils in the region are characterized by a sandy texture and relatively low $\mathrm{pH}$ which gives an enhanced risk for uptake of these metals in crops and leaching to groundwater, resulting in food and fodder crops that often exceed European and Belgian legal threshold values for $\mathrm{Cd}$ in particular (Witters et al., 2012). By transitioning from food crops to biomass and energy species, the agricultural lands remain profitable to farmers (i.e. through renewable energy and materials generation and economic benefits), and contaminant linkages (e.g. soil - food pathways) are reduced, with long-term source remediation. Taking into account the marginal impact of the metals in the biomass on the energy conversion efficiency and on the potential use of the biomass and its residual (metal-enriched) products after conversion, clear carbon abatement benefits are seen with up to $14,000 \mathrm{~kg} \mathrm{CO}_{2}$ ha-1 $\mathrm{y}^{-1}$ net $\mathrm{CO}_{2}$ avoidance for silage maize crops grown at the site (Witters et al, 2012). 
GROs may be particularly valuable in combination with renewables generation (through biomass and biomaterials production but also through use with solar and wind power on brownfields or marginal land, USEPA, 2015; Gonsalvesh et al., in press) and with urban flood management strategies, providing rainfall interception, surface and groundwater flow management, soil erosion prevention and reduced impermeable surface area, which allows their effective integration with sustainable urban drainage (SUDS) strategies (e.g. Kennen and Kirkwood, 2015). "Greened" urban areas may also play an important role in reducing urban contaminant transfer to water bodies (e.g. recent studies in Manchester, U.K. indicate that zinc and hydrocarbon delivery to urban drainage systems could be reduced by expanding green infrastructure, Rothwell et al., 2015).

Although GROs may be seen as "green" or more environmentally-friendly remediation options, particularly by local stakeholders (e.g. Hesske et al., 1998; Glass 1999), they are not however automatically sustainable - the overall economic, environmental and societal benefits depend on local site circumstances (such as the need for irrigation, fertilizers, fencing, etc.), the presence of local conversion chains for the produced biomass, and the site design (e.g. a monoculture option vs. encouragement of a diverse site ecosystem, use of non-native or genetically modified species etc.). It is therefore important to identify and ideally quantify the full wider value that GRO strategies may provide, so that a balanced judgement of costs and benefits can be derived. A number of studies have proposed the use of GROs to trigger land regeneration in circumstances where the economic case for intervention is marginal due to their lower deployment cost (e.g. Vangronsveld et al., 2009; Kuppusamy et al., 2016 ${ }^{\mathrm{a}, \mathrm{b}}$ ) and, potentially, also by their linkage to other project services such as renewable material generation, public green space or amenity land provision, recovery of land values, etc. (e.g. Bardos et al., 2011; Andersson-Sköld et al., 2014). While some of the benefits from these services may be relatively readily quantified (e.g. economic return from biomass generation, uplift in surrounding land and housing values, and flood management value) others related to environmental and societal value may be much more difficult to monetise (e.g. Bardos et al., 2016). A number of recent studies have highlighted the potential health and societal benefits from urban parks and green space (e.g. Parks Victoria, 2015), which are highly compatible with GRO, and quantifying these wider benefits and value (above standard economic returns) will be important in leveraging funding for GRO application and soft site end-use more widely at vacant or underutilized sites.

\section{Concluding remarks.}

Gentle remediation options (GROs) show clear potential for practical risk management at a range of site types, coupled with wider economic, environmental and societal benefits. The GREENLAND project decision support tool (DST) and best practice guidance have been designed to provide a context and technical support for GROs application (focussed on metal(loid)-contaminated sites), an overview of their current state of development, risk management capability, and potential wider (sustainability) benefits, quick reference guides, high-level GRO technical applicability guides, and details of convincing pilot GRO applications within Europe. The guidance can be used to support site planning, options appraisal, stakeholder engagement and consideration of initial design scenarios, and wider education of the potential risk management capacity and economic, environmental and societal benefits of GROs. The guidance, and the GREENLAND project more widely, promotes a 
refocus from phytoremediation to phytomanagement-based approaches, which places realisation of wider benefits at the core of site design and where gentle remediation technologies can be used as part of integrated, mixed, site risk management solutions, or as part of "holding strategies" for vacant sites. The combination of GROs with renewables, both in terms of biomass generation but also with green technologies such as wind and solar power, can provide a range of economic and other benefits and can potentially support the return of low-level contaminated sites to productive usage, while combining GROs with urban design and landscape architecture, and integrating GRO strategies with sustainable urban drainage systems and community gardens/parkland (particularly for health and leisure benefits), has large potential for triggering GRO application and in realising wider benefits in urban and suburban systems. Quantifying these wider benefits and value (above standard economic returns) will be important in leveraging funding for GRO application and soft site end-use more widely at vacant or underutilized sites.

\section{Acknowledgements.}

Further details of the GREENLAND project, and downloadable versions of the GREENLAND decision support tool and GRO best practice guidance, can be found at http://www.greenland-project.eu. The authors are grateful for financial support from the European Commission under the Seventh Framework Programme for Research (FP7-KBBE-266124), and thank the wider GREENLAND consortium and project advisory board for their support and input during the development of the DST and GRO best practice guidance.

\section{References.}

Anderson, C.W.N., Brooks, R.R, Chiarucci, A., LaCoste, C.J., Leblanc, M., Robinson, B.H., Simcock, R., Stewart, R.B., 1999. Phytomining for nickel, thallium and gold. J. Geochem. Explor. 67(1-3), 407-415.

Andersson-Sköld, Y., Bardos, R.P., Track, T., 2013. Crop Based Systems for Sustainable Risk Based Land Management for Economically Marginal Degraded Land: Short Guide for Decision Support Tool. REJUVENATE. Available at: http://snowmannetwork.com/wp-content/uploads/Rejuvenate-DSTguide 130329.pdf. (Accessed: January 20, 2016)

Andersson-Sköld Y., Bardos R.P., Chalot M., Bert V., Crutu G., Phanthavongsa P., Delplanque M., Track T., Cundy A.B., 2014. Developing and validating a practical decision support tool (DST) for biomass selection on marginal land. J. Environ. Manage. 145, 113-121.

ANL (Argonne National Laboratory), 2008. Re-greening of Murdock wetlands is a joint effort. Available at: www.anl.gov/articles/re-greening-murdock-wetlands-joint-effort (Accessed: January 20, 2016)

Bardos, R., Bone, B., Andersson-Sköld, Y., Suer, P., Track, T., Wagelmans, M., 2011. Crop-based systems for sustainable risk-based land management for economically marginal damaged land. Remediation, Autumn 2011, 11-33.

Bardos, P., Jones, S., Stephenson, I., Menger, P., Beumer, V., Neonato, F., Maring, L., Ferber, U., Track, T., Wendler, K., 2016. Optimising value from the soft re-use of brownfield sites. Sci. Total Environ. (in press) DOI: 10.1016/j.scitotenv.2015.12.002.

Basol, 2016. Base de données BASOL sur les sites et sols pollués (ou potentiellement pollués) appelant une action des pouvoirs publics, à titre préventif ou curative. http://basol.developpementdurable.gouv.fr/tableaux/home.htm (in French) (Accessed: January 20, 2016).

BBP Regeneration, 2008. Interim Evaluation of the East Kent Coalfields for SEEDA. Available at: http://www.homesandcommunities.co.uk/interim-evaluation-east-kent-coalfields. (Accessed: January 25, 2016) 
Becerra-Castro, C., Monterroso, C., Prieto-Fernández, A., Rodríguez-Lamas, L., Loureiro-Viñas, M., Acea, M.J., Kidd, P.S., 2012. Pseudometallophytes colonising $\mathrm{Pb} / \mathrm{Zn}$ mine tailings: a description of the plantmicroorganism-rhizosphere soil system and isolation of metal-tolerant bacteria. J. Hazard. Mater. 217-218, 350-359. DOI: 10.1016/j.jhazmat.2012.03.039.

Beesley, L., 2012. Carbon storage and fluxes in existing and newly created urban soils. J. Environ. Manage. 104, 158-165. DOI: 10.1016/j.jenvman.2012.03.024.

Bert, V., Seuntjens, P., Dejonghe, W., Lacherez, S., Thuy, H.T., Vandecasteele, B., 2009. Phytoremediation as a management option for contaminated sediments in tidal marshes, flood control areas and dredged sediment landfill sites. Environ. Sci. Pollut. Res. Int. 16,745-764. DOI: 10.1007/s11356-009-0205-6.

Bert, V., Hadj-Sahraoui, A., Leyval, C., Fontaine, J., Ouvrard, S., 2012a. Les phytotechnologies appliquées aux sites et sols pollués. Etat de l'art et guide de mise en œuvre. EDP Sciences. ISBN: 978-2-7598-0805-2.

Bert. V., Lors, C.H., Ponge, J.F., Caron, L., Biaz, A., Dazy, M., Masfaraud, J.F., 2012b. Metal immobilization and soil amendment efficiency at a contaminated sediment landfill site: A field study focusing on plants, springtails, and bacteria. Environ. Pollut. 169, 1-11. DOI: 10.1016/j.envpol.2012.04.021.

Bes, C., Mench, M., 2008. Remediation of copper-contaminated topsoils from a wood treatment facility using in situ stabilisation. Environ. Pollut. 156(3), 1128-1138. DOI:10.1016/j.envpol.2008.04.006.

Bolan, N., Kunhikrishnan, A., Thangarajana, R., Kumpiene, J., Parke, J., Makino, T., Kirkham, M.B., Scheckel, K., 2014. Remediation of heavy metal(loid)-contaminated soils - To mobilize or to immobilize? J. Hazard. Mater. 266, 141-166.

Cao, Z., Wang, S., Wang, T., Chang, Z., Shen, Z., Chen, Y., 2015. Using contaminated plants involved in phytoremediation for anaerobic digestion. Int. J. Phytoremediation, 17, 201-207.

Chen, S.B., Zhu, Y.G., Ma, Y.B., McKay, G., 2006. Effect of bone char application on Pb bioavailability in a Pbcontaminated soil. Environ. Pollut. 139(3), 433-439. DOI: 10.1016/j.envpol.2005.06.007.

CL:AIRE (Contaminated Land: Applications in Real Environments), 2008. SUB10: The Use of Compost in the Regeneration of Brownfield Land. Available at: http://www.forestry.gov.uk/pdf/SUBRIM bulletin 10.pdf/\$file/SUBRIM bulletin 10.pdf _(Accessed: January 20, 2016)

CL:AIRE (Contaminated Land: Applications in Real Environments), 2012. Cluster Guide. Available at: $\underline{C L: A I R E}$ hub and cluster guide (Accessed: January 20, 2016)

Commissariat Général au Développement Durable 2013. Basol: un panorama des sites et sols pollués, ou potentiellement pollués, nécessitant une action des pouvoirs publics. Études \& documents, $\mathrm{n}^{\circ} 97$ Novembre 2013 http://www.developpement-durable.gouv.fr/IMG/pdf/ED97.pdf.

Cundy, A.B., Bardos, R.P., Church, A., Puschenreiter, M., Friesl-Hanl, W., Müller, I., Neu, S., Mench, M., Witters, N., Vangronsveld, J., 2013. Developing principles of sustainability and stakeholder engagement for "gentle" remediation approaches: the European context. J. Environ. Manage. 129, 283-291. DOI: 10.1016/j.jenvman.2013.07.032.

Cundy, A.B., Bardos, R.P., Puschenreiter, M., Witters, N., Mench, M., Bert, V., Friesl-Hanl, W., Mueller, I., Weyens, N., Vangronsveld J., 2015. Developing effective decision support for the application of "gentle" remediation options: The GREENLAND project. Remediation, Summer 2015, 101-114.

Dadrasnia, A., Agamuthu, P., 2013. Organic wastes to enhance phyto-treatment of diesel-contaminated soil. Waste Manag. Res. 31(11), 1133-1139. DOI: 10.1177/0734242X13502382.

Delplanque, M., Collet, S., Gratta, F.D., Schnuriger, B., Gaucher, R., Robinson, B., Bert, V., 2013. Combustion of Salix used for phytoextraction: The fate of metals and viability of the processes. Biomass Bioenergy 49, 160170. DOI: 10.1016/j.biombioe.2012.12.026.

Denyes, M.J., Rutter, A., Zeeb, B.A., 2013. In situ application of activated carbon and biochar to PCBcontaminated soil and the effects of mixing regime. Environ. Pollut. 182, 201-208. DOI: 10.1016/j.envpol.2013.07.016.

Dietzsch, 2011. Utilisation of contaminated soils (in German). Saxon State Office for Environment, Agriculture and Geology, Dresden. Available at: https://publikationen.sachsen.de/bdb/artikel/14994/documents/17993. (Accessed: January 25, 2016).

Dimitriou, I., Aronsson, P., 2005. Willows for energy and phytoremediation in Sweden. Unasylva 221, 56, 4750.

Dimitriou, I., Rutz, D., 2015. Sustainable Short Rotation Coppice: A Handbook. WIP Renewable Energies, Munich, Germany. ISBN: 978-3-936338-36-2.

Escande, V., Olszewski, T.K., Grison, C., 2015. From biodiversity to catalytic diversity: how to control the reaction mechanism by the nature of metallophytes. Environ. Sci. Pollut. Res. Int. 22, 5653-66. doi: 10.1007/s11356-014-3483-6. 
ECL (Enviros Consulting Limited), CL: AIRE (Contaminated Land: Applications in Real Environments), 2006. Uses of compost in regeneration and remediation of brownfield sites in the UK, The Waste \& Resour. Action Programme 2006, p. 34, ISBN: 1-84405-265-6. Available at: http://www2.wrap.org.uk/downloads/Brownfield_market_potential_summary090506.8c2d6988.2841.pdf, (accessed 20.01.16.).

Evangelou, M.W.H., Robinson, B.H., Conesa, H.M., Schulin, R., 2012. Biomass production on trace element (TE) contaminated land-a review. Environ. Eng. Sci. 29, 823-839. doi: 10.1089/ees.2011.0428

Evangelou, M.W.H., Papazoglou, E.G., Robinson, B.H., Schulin, R., 2015. Phytomanagement: Phytoremediation and the Production of Biomass for Economic Revenue on Contaminated Land. In: Phytoremediation: Management of Environmental Contaminants, Volume 1, Springer International Publishing, 115-132.

Fässler, E., Robinson, B.H., Stauffer, W., Gupta, S.K., Papritz, A., Schulin, R., 2010. Phytomanagement of metalcontaminated agricultural land using sunflower, maize and tobacco. Agri. Ecosys. Environ. 136, 49-58. doi: 10.1016/j.agee.2009.11.007

Friesl, W., Friedl, J., Platzer, K., Horak, O., Gerzabek, M.H., 2006. Remediation of contaminated soils in the vicinity of a former $\mathrm{Pb} / \mathrm{Zn}$ smelter in Austria: Batch, pot, and field experiments. Environ. Pollut. 144 (1), 4050. DOI: 10.1016/j.envpol.2006.01.012.

Friesl-Hanl, W., Platzer, K., Horak, O., Gerzabek, M.H., 2009. Immobilising of Cd, Pb, and Zn contaminated arable soils close to a former $\mathrm{Pb} / \mathrm{Zn}$ smelter: a field study in Austria over 5 years. Environ. Geochem. Health 31(5), 581-94. DOI: 10.1007/s10653-009-9256-3.

Gandolfi, I., Sicolo, M., Franzetti, A., Fontanarosa, E., Santagostino, A., Bestetti, G., 2010. Influence of compost amendment on microbial community and ecotoxicity of hydrocarbon-contaminated soils. Bioresource Technol. 101(2), 568-575. DOI: 10.1016/j.biortech.2009.08.095.

Glass, D.J., 1999. Current market trends in phytoremediation. Int. J. Phytoremediation, 1(1), 1-8. DOI: 10.1080/15226519908500001.

Gonsalvesh, L., Yperman, J., Carleer, R., Mench, M., Herzig, R., Vangronsveld, J., (in press) Valorisation of heavy metals enriched tobacco biomass through slow pyrolysis and steam activation. J. Chem. Tech. Biotech. DOI: 10.1002/jctb.4889

Gray, C.W., Dunham, S.J., Dennis, P.G., Zhao, F.J., McGrath, S.P., 2006. Field evaluation of in situ remediation of a heavy metal contaminated soil using lime and red-mud. Environ. Pollut. 142(3), 530-539. DOI: 10.1016/j.envpol.2005.10.017.

GREENLAND. Gentle remediation options (GRO). Available at: www.greenland-project.eu (Accessed: January 20, 2016)

Hartley, W., Dickinson, N.M., Riby, P., Lepp, N.W., 2009. Arsenic mobility in brownfield soils amended with green waste compost or biochar and planted with Miscanthus. Environ. Pollut. 157(10), 2654-2662. DOI: 10.1016/j.envpol.2009.05.011.

Hattab, N., Motelica-Heino, M., Bourrat, X., Mench, M., 2014. Mobility and phytoavailability of Cu, Cr, Zn, and As in a contaminated soil at a wood preservation site after 4 years of aided phytostabilization. Environ. Sci. Pollut. Res. Int. 21(17), 10307-10319. DOI: 10.1007/s11356-014-2938-0.

Hattab, N., Motelica-Heino, M., Mench, M., 2016. Aided phytoextraction of $\mathrm{Cu}, \mathrm{Pb}, \mathrm{Zn}$, and As in coppercontaminated soils with tobacco and sunflower in crop rotation: Mobility and phytoavailability assessment. Chemosphere 145, 543-550.

Heinsoo, K., Dimitriou, I., 2014. Growth performance of willow clones in short rotation coppice after sewage sludge application. Baltic Forestry 20(1), 70-77.

Herzig, R., Ricci, A., Nehnevajova, E., Schwitzguébel, J.P., 2008. Assessing of the phytoextraction efficiency for soluble zinc and other heavy metals from a contaminated top soil using biotechnologically improved tobacco and sunflower mutants and appropriate fertilization techniques, in: Phytotechnologies in practice-biomass production, agricultural methods, legacy, legal and economic aspects. COST Action 859 Management Committee and WG4 Meeting, Verneuilen-Halatte, France, pp, 20-22.

Herzig, R., et al., 2009. Weiterführung der Phytoremediation 2008 am zinkbelasteten Deponiestandort "Grüenau-Buech-Alpenblick" in Bettwiesenim Auftrag der IMMO-DEVELOPMENT AG. 3. Interner Zwischenbericht 4.2.2009.

Herzig, R., Nehnevajova, E., Pfistner, C., Schwitzguebel, J.P., Ricci, A., Keller, C., 2014. Feasibility of labile Zn phytoextraction using enhanced tobacco and sunflower: Results of five- and one-year field-scale experiments in Switzerland. Int. J. Phytoremediation 16(7-8), 735-754. DOI: 10.1080/15226514.2013.856846. 
Hesske, S., Schärli, M., Tietje O., Scholz, R.W., 1998. Zum Umgang mit Schwermetallen im Boden: Falldossier Dornach. Pabst Sciences Publishers, Lengerich.

HOMBRE (Holistic Management of Brownfield Regeneration), 2013. D 5.1: Valuation approach for services from regeneration of Brownfields for soft re-use on a permanent or interim basis: Creating opportunities from synergies between environmental, economic and social improvements. Available at: http://www.zerobrownfields.eu/HombreTrainingGallery/HomePage/HOMBRE D5.1 final Services SoftRe Use.pdf (Accessed: January 20, 2016)

HOMBRE (Holistic Management of Brownfield Regeneration), 2014. D 5.4: Operating Windows of Two Important Low Input Technologies for Greening Urban Brownfield. Available at: http://www.zerobrownfields.eu/HombreTrainingGallery/HOMBRE D5.4 final.pdf (Accessed: January 20, 2016)

Huguet, S., Bert, V., Laboudigue, A., Barthes, V., Isaure, M.P., Llorens, I., Schat, H., Sarret, G., 2012. Cd speciation and localization in the hyperaccumulator Arabidopsis halleri. Environ. Exp. Bot. 82, 54-65. DOI: 10.1016/j.envexpbot.2012.03.011.

Interstate Technology Regulatory Council (ITRC), 2009. Phytotechnology Technical and Regulatory Guidance and Decision Trees, Revised. Washington DC, USA, p. 125. www.itrcweb.org.

Janssen, J.A., 2015. Metal phytoextraction: the potential of high biomass crops and improving efficiency using short rotation coppice (SRC) willow. Chapter 3: Phytoextraction of $\mathrm{Cd}-\mathrm{Zn}$-Pb-contaminated soil using high biomass crops: potential of tobacco, sunflower, hemp and SRC of willow and poplar. Unpub. PhD thesis, Hasselt University, Belgium. pp 55-120.

Jones, S., Bardos, R.P., Kidd, P.S., Mench, M., de Leij, F., Hutchings, A., Cundy, A.B., Joyce, C., Soja, G., FrieslHanl, W., Herzig, R., Menger, P., 2016. Biochar and compost amendments enhance copper immobilisation and support plant growth in a contaminated soil. J. Environ. Manage. 171, 101-112. DOI: 10.1016/j.jenvman.2016.01.024.

Kennen, K., Kirkwood, N., 2015. Phyto: Principles and resources for site remediation and landscape design. Routledge, London, p. 346.

Kidd, P., Álvarez-López, V., Rodrí guez-Garrido, B., Trasar-Cepeda, C., Touceda-González, M., Mench, M., Puschenreiter, M., Macías-García, F., Prieto-Fernández, A., 2014. (Aided)-phytostabilisation of Cu-rich mine tailings using woody crops and grass species. Proceedings of the 10th International Phytotechnologies Conference, Crete, Greece.

Kidd, P., Mench, M., Alvarez-Lopez, V., Bert, V., Dimitriou, I., Friesl-Hanl, W., Herzig, R., Janssen, J.A., Kolbas, A., Mueller, I., Neu, S., Renella, G., Ruttens, A., Vangronsveld, J., Puschenreiter, M., 2015. Agronomic practices for improving gentle remediation of trace-element contaminated soils. Int. J. Phytoremediation 17, 10051037. doi: 10.1080/15226514.2014.1003788

Kolbas, A., Mench, M., Herzig, R., Nehnevajova, E., Bes, C.M., 2011. Copper phytoextraction in tandem with oilseed production using commercial cultivars and mutant lines of sunflower. Int. J. Phytoremediation 13(1), 55-76. DOI: 10.1080/15226514.2011.568536.

Kumar, S., Loganathan, V.A., Gupta, R.B., Barnett, M.O., 2011. An Assessment of U(VI) removal from groundwater using biochar produced from hydrothermal carbonization. J. Environ. Manage. 92(10), 25042512. DOI: 10.1016/j.jenvman.2011.05.013.

Kumpiene, J., Lagerkvist, A., Maurice, C., 2008. Stabilization of $\mathrm{As}, \mathrm{Cr}, \mathrm{Cu}, \mathrm{Pb}$ and $\mathrm{Zn}$ in soil using amendments a review. Waste Manag. 28, 215-25. doi: 10.1016/j.wasman.2006.12.012

Kuppusamy, S., Palanisami, T., Megharaj, M., Venkateswarlu, K., Naidu, R., 2016a. In-Situ Remediation Approaches for the Management of Contaminated Sites: A Comprehensive Overview. In: P. de Voogt (ed.), Reviews of Environmental Contamination and Toxicology, Volume 236, Reviews of Environmental Contamination and Toxicology 236, DOI 10.1007/978-3-319-20013-2_1. Springer International Publishing, Switzerland 2016.

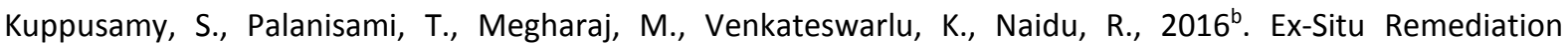
Technologies for Environmental Pollutants: A Critical Perspective. In: P. de Voogt (ed.), Reviews of Environmental Contamination and Toxicology, Volume 236, Reviews of Environmental Contamination and Toxicology 236, DOI 10.1007/978-3-319-20013-2_2. Springer International Publishing, Switzerland 2016.

Lagomarsino, A., Mench, M., Marabottini, R., Pignataro, A., Grego, S., Renella, G, Stazi, S.R., 2011. Copper distribution and hydrolase activities in a contaminated soil amended with dolomitic limestone and compost. Ecotox. Environ. Safe. 74(7), 2013-2019. DOI: 10.1016/j.ecoenv.2011.06.013.

Lee, S.H., Lee, J.S., Choi, Y.J., Kim, J.G, 2009. In situ stabilization of cadmium-, lead-, and zinc-contaminated soil using various amendments. Chemosphere 77(8), 1069-1075. DOI: 10.1016/j.chemosphere.2009.08.056 
LfULG, 2008. Managing contaminated soil - Managing grassland and producing biomass as energy and Csource on sites at different level of contamination by metals (in German). Schriftenreihe des Landesamtes für Umwelt, Landwirtschaft und Geologie. Heft 30/2008, 150 P., Dresden, Germany

Liang, Y., Cao, X.D., Zhao, L., Arellano, E., 2014. Biochar- and phosphate-induced immobilization of heavy metals in contaminated soil and water: implication on simultaneous remediation of contaminated soil and groundwater. Environ. Sci. Pollut. Res. Int. 21(6), 4665-4674. DOI: 10.1007/s11356-013-2423-1.

Lord, R., Green, R., Oyekanmi, E., Atkinson, J., Parry, C., Bridgewood, K., 2010. Green waste for greening brownfields: Using compost to establish energy crops on previously developed land. Available at: http://ec.europa.eu/environment/life/project/Projects/index.cfm?fuseaction=home.showFile\&rep=file\&fil =BIOREGEN Green Waste.pdf (Accessed: January 20, 2016)

LRUG (Land Reclamation and Urban Greening), Sustainable woodland remediation solutions for multifunctional sites. Available at: http://www.forestry.gov.uk/pdf/Land rec brochure.pdf/\$FILE/Land rec brochure.pdf (Accessed: January 20, 2016)

Marchand, L., Quintela-Sabaris, C., Desjardins, D., Oustrière, N., Pesme, E., Butin, D., Wicart G., Mench, M., 2015. Plant responses to a phytomanaged urban technosol contaminated by trace elements and polycyclic aromatic hydrocarbons. Environ. Sci. Pollut. Res. (on line) Doi 10.1007/s11356-015-4984-7

Marschner, B., Müller, I., Stolz, R., Stempelmann, I., 2010. Immobilizing heavy metals in garden soil - results from a 5-year field test (in German), Zeitschrift Bodenschutz 02/2010, S. 34-41.

Marschner, B., Haag, R., Stolz, R., Müller, I., Stempelmann, I., 2011. Effects of soil amendments on heavy metal mobility, plant uptake and microbial activity during a 5-year field trial. ICOBTE 03.07.2011 - 08.07.2011, Florence, Italy.

Meers, E., Van Slycken, S., Adriaensen, K., Ruttens, A., Vangronsveld, J., Du Laing, G., Witters, N., Thewys, T., Tack, F.M., 2010. The use of bio-energy crops (Zea mays) for 'phytoattenuation' of heavy metals on moderately contaminated soils: a field experiment. Chemosphere 78(1), 35-41. DOI: 10.1016/j.chemosphere.2009.08.015.

Mench, M., Schwitzguébel, J.P., Schröder P., Bert, V., Gawronski, S., Gupta, S., 2009. Assessment of successful experiments and limitations of phytotechnologies: contaminant uptake, detoxification and sequestration, and consequences for food safety. Environ. Sci. Pollut. Res. 16, 876-900 (DOI 10.1007/s11356-009-0252-z).

Mench, M., Lepp, N., Bert, V., Schwitzguebel, J.P., Gawronski, S.W., Schroeder, P., Vangronsveld, J. 2010. Successes and limitations of phytotechnologies at field scale: outcomes, assessment and outlook from COST Action 859. J. Soil Sediment 10:1039-1070. doi:10.1007/s11368-010-0190-x

Monterroso, C., Rodríguez, F., Chaves, R., Diez, J., Becerra-Castro, C., Kidd, P.S., Macías, F., 2014. Heavy metal distribution in mine-soils and plants growing in a Pb/Zn-mining area in NW Spain. Appl. Geochem. 44, 3-11. DOI: 10.1016/j.apgeochem.2013.09.001.

Neu, S., Müller, I., 2014. Gentle remediation options (GRO) for the management of large-scale contaminated agricultural sites in Saxony, Germany. Proc. CABERNET 2014: Tailored \& Sustainable Redevelopment towards Zero Brownfields, 4th International Conference on Managing Urban Land. 14th - 16th October 2014, Frankfurt am Main, Germany

Nsanganwimana, F., Pourrut, B., Mench, M., Douay, F., 2014. Suitability of Miscanthus species for managing inorganic and organic contaminated land and restoring ecosystem services. A review. J. Environ. Manage. 143, 123-134. Doi: 10.1016/j.jenvman.2014.04.027

Onwubuya, K., Cundy, A.B., Puschenreiter, M., Kumpiene, J., Greaves, J., Teasdale, P., Mench, M., Tlustos, P., Mikhalovsky, S., Waite, S., Friesl, W., Marschner B., Mueller, I., 2009. Developing decision support tools for the selection of "Gentle" remediation approaches. Sci. Total Environ. 407, 6132 - 6142.

Palmer, M., Davies, R., 2008. Final report - Lambton Former Coke Works. Published by: The Waste \& Resources Action Programme. Available at: http://www2.wrap.org.uk/downloads/Approved version Lambton 2008 report - FINAL.6251272b.6774.pdf (Accessed: January 20, 2016)

Panagos, P., Van Liedekerke, M., Yigini, Y., Montana, L., 2013. Contaminated sites in Europe: Review of the current situation based on data collected through a European network. J. Environ. Public Health, Article ID 158764, 11 pages. doi: 10.1155/2013/158764

Parks Victoria, 2015. Healthy Parks Healthy People: The state of the evidence 2015. http://www.hphpcentral.com/wp-content/uploads/2015/07/HPHP state-of-the-evidence 2015.pdf (Accessed: January 30, 2016).

Paulson, M., Bardos, P., Harmsen, J., Wilczek, J., Barton, M., Edwards, D., 2003. The practical use of short rotation coppice in land restoration. Land Contamination Reclamation 11 (3), 323-338. DOI: 10.2462/09670513.624. 
Peuke, A.D., Rennenberg, H., 2005. Phytoremediation: Molecular biology, requirements for application, environmental protection, public attention and feasibility. EMBO reports, 6(6), 497-501.

Pivetz, B.E., 2001. Phytoremediation of Contaminated Soil and Ground Water at Hazardous Waste Sites. EPA/540/S-01/500. Available at: http://www.epa.gov/superfund/remedytech/tsp/download/epa 540 s01 500.pdf (Accessed: January 20, 2016)

Puschenreiter, M., the SUMATECS consortium, 2009. Sustainable Management of Trace Element Contaminated Soils - Development of a Decision Tool System and Its Evaluation for Practical Application. Final report, Project No. SN-01/20, 2009 (SNOWMAN-ERANET) www.snowmanera.net/downloads/SUMATECS_FINAL_REPORT.pdf.

Qantas, Shell Australia, SKM (Sinclair Knight Merz), SkyNRG, AltAir Fuels, Solena Fuels, University of Adelaide, 2013. Feasibility Study of Australian feedstock and production capacity to produce sustainable aviation fuel. Available at: https://www.qantas.com.au/infodetail/about/environment/aviation-biofuel-report.pdf (Accessed: January 20, 2016)

Rothwell J.J., Causer K., Simmons P., Savage M., 2015. Gully pots as hotspots of urban diffuse pollution. Key findings from the Gully Pot Project. The University of Manchester. Unpublished report.

Robinson, B.H., Anderson, C.W.N., Dickinson, N.M., 2015. Phytoextraction: Where's the action? J. Geochem. Explor. 151 34-40.

Ruttens, A., Boulet, J., Weyens, N., Smeets, K., Adriaensen, K., Meers, E., Van Slycken, S., Tack, F., Meiresonne, L., Thewys, T., Witters, N., Carleer, R., Dupae, J., Vangronsveld, J., 2011. Short rotation coppice culture of willow and poplar as energy crops on metal contaminated agricultural soils. Int. J. Phytoremediation. 13, 194-207. DOI: 10.1080/15226514.2011.568543.

Siebielec, G., Stuczyński, T., Korzeniowska-Pucułek, R., 2006. Metal bioavailability in long-term contaminated Tarnowskie Gory soils. Pol. J. Environ. Stud. 15, 121-129.

Tandy, S., Healey, J.R., Nason, M.A., Williamson, J.C., Jones, D.L., 2008. Remediation of metal polluted mine soil with compost: Co-composting versus incorporation. Environ. Pollut. 157(2), 690-697. DOI: 10.1016/j.envpol.2008.08.006.

Treating Wastes for Restoring Land Sustainability. TWIRLS: LIFE04 ENV/UK/000820. Available at: http://ec.europa.eu/environment/life/project/Projects/index.cfm?fuseaction=home.showFile\&rep=file\&fil $=$ LIFE04 ENV GB 000820 LAYMAN.pdf (Accessed: January 20, 2016)

UBA, 2015. Register of contaminated sites in Germany - Federal survey. Umweltbundesamt; based on data provided by all federal states; reference date 24.08.2015. http://www.umweltbundesamt.de/daten/bodenbelastung-land-oekosysteme/altlasten-ihre-sanierung

Uchimiy, M., Lim, I. M., Klasson, K.T., Chang, S., Wartelle, L.H., Rodgers, J.E., 2010. Immobilization of heavy metal ions (Cull, CdII, Nill, and PbIl) by broiler litter-derived BC in water and soil. J. Agr. Food Chem. 58(9), 5538-5544. DOI: 10.1021/jf9044217.

USEPA (United States Environmental Protection Agency), 2007. Phytotechnology Project Profiles: Phytoremediation at a creek tributary site in Nebraska. Available at: www.cluin.org/products/phyto/search/phyto details.cfm?ProjectID=187 (Accessed: January 20, 2016)

USEPA (United States Environmental Protection Agency), 2010. From Brown to Green: Restoring Ecosystems on Former Brownfields. Available at: http://www.epa.gov/brownfields/success/ecological_restoration_ss 071310.pdf (Accessed: January 20, 2016)

USEPA (United States Environmental Protection Agency), 2015. RE-Powering America's Land. Siting Renewable Energy on Potentially Contaminated Lands, Landfills, and Mine Sites. Available at: http://www.epa.gov/repowering (Accessed January 24, 2016).

USEPA (United States Environmental Protection Agency), 2015. Using Phytoremediation to Clean Up Sites. Available at: www.epa.gov/superfund/accomp/news/phyto.htm (Accessed: January 20, 2016)

USEPA (United States Environmental Protection Agency), SWER (Solid Waste and Emergency Response), 1997. Innovative Uses of Compost: Reforestation, Wetlands Restoration, and Habitat Revitalization. Available at: http://www.epa.gov/sites/production/files/2015-08/documents/reforest.pdf (Accessed: January 20, 2016)

Vangronsveld, J., Colpaert, J., Van Tichelen, K., Clijsters, H. 1995ª. Reclamation of a bare industrial area contaminated by non-ferrous metals: physico-chemical and biological evaluation of the durability of soil treatment and revegetation. Environ. Pollut., 94, 131-140.

Vangronsveld, J., Sterckx, J., Van Assche, F., Clijsters, H., 1995 ${ }^{\mathrm{b}}$. Rehabilitation studies on an old non-ferrous waste dumping ground: effects of revegetation and metal immobilization by beringite. J. Geochem. Explor. 52, 221-229 
Vangronsveld, J., Herzig, R., Weyens, N., Boulet, J., Adriaensen, K., Ruttens, A., Thewys, T., Vassilev, A., Meers, E., Nehnevajova, E., van der Lelie, D., Mench, M., 2009. Phytoremediation of contaminated soils and groundwater: lessons from the field. Environ. Sci. Pollut. Res. Int. 16(7), 765-794. DOI: 10.1007/s11356009-0213-6.

Van Slycken, S., Witters, N., Meiresonne, L., Meers, E., Ruttens, A., Van Peteghem, P., Weyens, N., Tack, F.M.G., Vangronsveld, J., 2013 ${ }^{\text {a }}$. Field evaluation of willows under short rotation coppice for phytomanagement of metal-polluted agricultural soils. Int. J. Phytoremediation, 15 (7), 677 e689.

Van Slycken, S., Witters, N., Meers, E., Peene, A., Michels, E., Adriaensen, K., Ruttens, A., Vangronsveld, J., Du Laing, G., Wierinck, I., Van Dael, M., Van Passel, S., Tack, F.M.G., 2013 ${ }^{\text {b }}$. Safe use of metal-contaminated agricultural land by cultivation of energy maize (Zea mays). Environ. Pollut. 178, 375e380

Wilczek, J., 2004. Markham Willows Masterplanning: Final report. Available at: http://www.r3environmental.co.uk/downloadsnew/mwover.pdf (Accessed: January 20, 2016)

Witters, N., Van Slycken, S., Ruttens, A., Adriaensen, K., Meers, E., Meiresonne, L, Vangronsveld, J., Tack, F.M.G., Thewys, T., Laes, E., 2009. Short Rotation Coppice of willow for phyto-remediation of a metalcontaminated agricultural area: a sustainability assessment. BioEnergy Res. 2(3), 144-152. DOI: $10.1007 / \mathrm{s} 12155-009-9042-1$.

Witters, N., Mendelsohn, R.O., Van Slycken, S., Weyens, N., Schreurs, E., Meers, E., Tack, F., Carleer, R., Vangronsveld, J., 2012. Phytoremediation, a sustainable remediation technology? Conclusions from a case study. I: Energy production and carbon dioxide abatement. Biomass Bioenergy 39, 454-469. DOI: 10.1016/j.biombioe.2011.08.016.

Wójcik, M., Sugier, P., Siebielec, G., 2014. Metal accumulation strategies in plants spontaneously inhabiting Zn$\mathrm{Pb}$ waste deposits. Sci. Total Environ. 487, 313-322. DOI: 10.1016/j.scitotenv.2014.04.024.

WRAP (The Waste \& Resources Action Programme), 2007. Quality compost opens up new uses for brownfield land on Teesside: The case for greener brownfield regeneration. Available at: http://ec.europa.eu/environment/life/project/Projects/index.cfm?fuseaction=home.showFile\&rep=file\&fil =BIOREGEN Case Study WRAP.pdf (Accessed: January 20, 2016)

WRAP (The Waste \& Resources Action Programme), 2009. Transforming Ebbw Vale - from steelworks to green space. Available at: $\quad$ http://www.wrapcymru.org.uk/sites/files/wrap/case\%20study\%20\%20Ebbw\%20Vale.pdf (Accessed: January 20, 2016)

WRAP (The Waste \& Resources Action Programme), 2012. Good Practice Guide: Using PAS 100 compost in landscape and regeneration projects: Energy crops on brownfield land. Available at: http://www.wrap.org.uk/sites/files/wrap/WRAP\%20GPG\%204\%20Energy\%20crops\%20on\%20brownfield\% 20land.pdf (Accessed: January 20, 2016)

WRAP (The Waste \& Resources Action Programme). Quality compost helps Scottish quarry cut costs: The case for greener brownfield regeneration. Available at: http://www.wrap.org.uk/sites/files/wrap/WRAP Case\%20study Dunbar.pdf (Accessed: January 20, 2016)

Xiong, J., Madejón, P., Madejón, E., Cabrera, F., 2015. Assisted natural remediation of a trace elementcontaminated acid soil: An eight-year field study. Pedosphere 25(2), 250-262. DOI: 10.1016/S10020160(15)60010-8.

Xu, X.Y., Cao, X.D., Zhao, L., Wang, H.L., Yu, H.G., Gao, B., 2013. Removal of Cu, Zn, and Cd from aqueous solutions by the dairy manure-derived biochar. Environ. Sci. Pollut. Res. Int. 20(1), 358-368. DOI: 10.1007/s11356-012-0873-5.

Yang, X., Liu, J.J., McGrouther, K., Huang, H.G., Lu, K.P., Guo, X., He, L.Z., Lin, X.M., Che, L., Ye, Z.Q., Wang, H.L., 2016. Effect of biochar on the extractability of heavy metals ( $\mathrm{Cd}, \mathrm{Cu}, \mathrm{Pb}$, and $\mathrm{Zn}$ ) and enzyme activity in soil. Environ. Sci. Pollut. Res. Int. 23(2), 974-984. DOI: 10.1007/s11356-015-4233-0. 


\section{Table and figure captions.}

Table 1. Examples of Gentle Remediation Options used to remediate soils contaminated by either metal(loid)s or mixed contamination (after Peuke and Rennenberg, 2005, Mench et al., 2010, Cundy et al., 2015).

Table 2: The GREENLAND site network of GRO pilot trials at metal(loid) contaminated sites in Europe.

Table 3: Examples of wider benefits from the use of GROs. Adapted and expanded from the HOMBRE project Brownfield Opportunity Matrix (BOM, http://www.zerobrownfields.eu), a qualitative MS Excel-based screening tool which identifies potential services from soft re-use land regeneration strategies, Bardos et al., (2016).

Figure 1: Example risk management strategy using GROs customised along contaminant linkages. Out-facing arrows link to illustrative wider environmental, economic and societal benefits that may be realised from GRO application. After Cundy et al., (2013) and www.greenland-project.eu. See Section 4 for discussion. 
Table 1. Examples of Gentle Remediation Options used to remediate soils contaminated by either metal(loid)s or mixed contamination (after Peuke and Rennenberg, 2005, Mench et al., 2010, Cundy et al., 2015).

GRO Description

Phytoextraction

Phytodegradation / phytotransformation

Rhizodegradation

Rhizofiltration

Phytostabilization

Phytovolatilization

In situ immobilization / phytoexclusion
The removal of metal(loid)s or organics from soils by accumulation in the harvestable biomass of plants. When aided by use of soil amendments (e.g. EDTA or other mobilising agents), this is termed "aided phytoextraction".

The use of plants (and associated microorganisms such as rhizosphere and endophytic bacteria) to uptake, store and degrade or transform organic pollutants.

The use of plant roots and rhizosphere microorganisms to degrade organic pollutants.

The removal of metal(loid)s or organics from aqueous sources (including groundwater) by plant roots and associated microorganisms.

Reduction in the bioavailability of pollutants by immobilisation in root systems and/or living or dead biomass in the rhizosphere soil. When aided by use of soil amendments, this is termed "aided phytostabilization".

Use of plants to remove pollutants from the growth matrix, transform them and disperse them (or their derived products) into the atmosphere.

Reduction in the bioavailability of pollutants by immobilizing or binding them to the soil matrix through the incorporation into the soil of organic or inorganic compounds, singly or in combination, to prevent the excessive uptake of essential elements and non-essential contaminants into the food chain. Phytoexclusion, the implementation of a stable vegetation cover using socalled excluder plants which do not accumulate contaminants in the harvestable plant biomass, can be combined with in situ immobilization. 
Table 2: The GREENLAND site network of GRO pilot trials at metal(loid) contaminated sites in Europe.

\begin{tabular}{|c|c|c|c|c|c|}
\hline Location & Site type & Contaminants & GRO strategy & Plant species & Selected references \\
\hline Austria & Agricultural soils & $\mathrm{Cd}, \mathrm{Pb}, \mathrm{Zn}(\mathrm{As}, \mathrm{Cu})$ & $\begin{array}{l}\text { In situ stabilisation / } \\
\text { phytoexclusion }\end{array}$ & Crops (barley, maize) & Friesl et al., 2006; 2009 \\
\hline Belgium & Agricultural soils & $\mathrm{Cd}, \mathrm{Zn}, \mathrm{Pb}$ & Phytoextraction & $\begin{array}{l}\text { Poplars, willows, maize, } \\
\text { rapeseed, tobacco, sunflower, } \\
\text { hemp }\end{array}$ & $\begin{array}{l}\text { Meers et al., 2010; Ruttens et al., 2011; } \\
\text { Witters et al., 2012; Janssen, } 2015\end{array}$ \\
\hline France & $\begin{array}{l}\text { Industrial soil in } \\
\text { urban area }\end{array}$ & $\mathrm{Cd}, \mathrm{Zn}, \mathrm{Pb}$ & Phytoextraction & Arabidopsis halleri, willows & Bert et al., 2012a; Huguet et al., 2012 \\
\hline France & $\begin{array}{l}\text { Dredged sediment } \\
\text { landfill }\end{array}$ & $\mathrm{Cd}, \mathrm{Zn}, \mathrm{Pb}, \mathrm{As}, \mathrm{Cu}$ & Aided phytostabilisation & Tufted hair grass, willows & Bert et al., 2009, 2012a, 2012b \\
\hline France & Industrial soils & $\mathrm{Cu}$ and $\mathrm{Cu} / \mathrm{PAHs}$ & $\begin{array}{l}\text { Phytoextraction; } \\
\text { phytostabilisation and } \\
\text { rhizodegradation }\end{array}$ & $\begin{array}{l}\text { Sunflower, tobacco, sorghum, } \\
\text { poplars, willows, grasses, } \\
\text { vetiver }\end{array}$ & $\begin{array}{l}\text { Bes and Mench, 2008; Cundy et al., } \\
\text { 2013; Hattab et al., 2014, } 2016\end{array}$ \\
\hline Germany & Agricultural soils & $\mathrm{Cd}, \mathrm{Zn}, \mathrm{Pb}$ & $\begin{array}{l}\text { Phytoextraction; in situ } \\
\text { stabilisation/phytoexclusion }\end{array}$ & $\begin{array}{l}\text { Poplars, willows, crops, } \\
\text { grassland }\end{array}$ & Dietzsch, 2011; Cundy et al., 2013 \\
\hline Poland & Post-industrial soils & $\mathrm{Cd}, \mathrm{Zn}, \mathrm{Pb}$ & $\begin{array}{l}\text { In situ stabilisation / } \\
\text { phytoexclusion }\end{array}$ & Grassland & Siebielec et al., 2006; Wójcik et al., 2014 \\
\hline Spain & Tailings & $\mathrm{Cd}, \mathrm{Zn}$ & Phytoextraction & Noccaea caerulescens & $\begin{array}{l}\text { Becerra-Castro et al., 2012; Monterroso } \\
\text { et al., } 2014\end{array}$ \\
\hline Spain & Tailings & $\mathrm{Cu}$ & Phytostabilisation & Poplars, willows & Kidd et al., 2014; 2015 \\
\hline Sweden & $\begin{array}{l}\text { Commercial sludge- } \\
\text { amended fields }\end{array}$ & $\begin{array}{l}\mathrm{Cd}, \mathrm{Zn}(\mathrm{Cu}, \mathrm{Ni}, \mathrm{Cr} \\
\mathrm{Pb})\end{array}$ & Phytoextraction & Willows & $\begin{array}{l}\text { Heinsoo and Dimitriou (2014); Dimitriou } \\
\text { and Rutz (2015) }\end{array}$ \\
\hline Switzerland & $\begin{array}{l}\text { Agricultural soil on } \\
\text { former landfill }\end{array}$ & $\begin{array}{l}\text { Zn (with some } \mathrm{Cd} \text {, } \\
\mathrm{Cr} \text { and } \mathrm{Cu} \\
\text { contamination) }\end{array}$ & Phytoextraction & Sunflower, tobacco & Herzig et al., 2008; 2009; 2014 \\
\hline
\end{tabular}


Table 3: Examples of wider benefits from the use of GROs. Adapted and expanded from the HOMBRE project Brownfield Opportunity Matrix (BOM, http://www.zerobrownfields.eu), a qualitative MS Excel-based screening tool which identifies potential services from soft re-use land regeneration strategies, Bardos et al., (2016).

\section{A. Phyto-Remediation}

\begin{tabular}{|c|c|c|c|}
\hline General benefit & & Examples & Case Studies / citations \\
\hline \multirow{8}{*}{$\begin{array}{l}\text { Risk Mitigation } \\
\text { of } \\
\text { Contaminated } \\
\text { Land and } \\
\text { Groundwater }\end{array}$} & Biosphere & 15 full scale project examples are listed on the CLU-IN website which highlight the & www.clu- \\
\hline & (including & effectiveness of phytoremediation for human health / ecological risk management. & in.org/products/phyto/search/phyto list.cfm \\
\hline & human & Oregon Poplar site, J-field at Aberdeen Proving Ground. & EPA, 2015. \\
\hline & health) & $\begin{array}{l}\text { Risk mitigation at trace element contaminated sites using different phytoremediation } \\
\text { interventions. }\end{array}$ & $\begin{array}{l}\text { Herzig et al., 2014; Friesl-Hanl et al., 2009; } \\
\text { Hattab et al., } 2014 .\end{array}$ \\
\hline & Water & 15 full scale project examples are listed on the CLU-IN website, which show examples & $\underline{w w w . c l u-}$ \\
\hline & Resources & of the use of phytoremediation for water resource protection. & in.org/products/phyto/search/phyto list.cfm \\
\hline & (hydrosphere & Oregon Poplar site, J-field at Aberdeen Proving Ground. & EPA, 2015. \\
\hline & ) & $\begin{array}{l}\text { Risk mitigation at trace element contaminated sites using different phytoremediation } \\
\text { interventions. }\end{array}$ & $\begin{array}{l}\text { Herzig et al., 2014; Friesl-Hanl et al., 2009; Bert } \\
\text { et al. 2012; Hattab et al., 2014, 2016; Janssen, } \\
2015 .\end{array}$ \\
\hline $\begin{array}{l}\text { Soil } \\
\text { Improvement }\end{array}$ & $\begin{array}{l}\text { Fertility and } \\
\text { soil structure }\end{array}$ & $\begin{array}{l}\text { Maintenance or improvement in soil fertility and structure can occur directly through } \\
\text { vegetation and rhizosphere development, or through amendment addition. }\end{array}$ & $\begin{array}{l}\text { Herzig et al., 2014; Friesl-Hanl et al., 2009; } \\
\text { Nsanganwimana et al., 2014; Hattab et al., } \\
\text { 2014, 2016; Kidd et al., 2015; Evangelou et al., } \\
2015 .\end{array}$ \\
\hline \multirow{7}{*}{$\begin{array}{l}\text { Water } \\
\text { Resource } \\
\text { Improvement }\end{array}$} & $\begin{array}{l}\text { Water } \\
\text { resource }\end{array}$ & $\begin{array}{l}\text { Improvements in local water resources arising from phytoremediation application are } \\
\text { illustrated by an integrated phytoremediation system at Murdock, Nebraska, USA. }\end{array}$ & ANL, 2008; EPA, 2007. \\
\hline & $\begin{array}{l}\text { efficiency and } \\
\text { quality }\end{array}$ & Phytoremediation-based water treatment systems in Sweden. & Dimitriou and Aronsson, 2005. \\
\hline & Flood and & Potential of phytoremediation systems for hydraulic control. & Pivetz, 2001. \\
\hline & $\begin{array}{l}\text { capacity } \\
\text { management }\end{array}$ & $\begin{array}{l}\text { An integrated phytomanagement system at Murdock, Nebraska, USA illustrates how } \\
\text { system design can be used to control infiltration and water residence time and } \\
\text { decrease flood risk. }\end{array}$ & ANL, 2008. \\
\hline & $\begin{array}{l}\text { Rehabilitatio } \\
\text { n of water }\end{array}$ & $\begin{array}{l}\text { Rehabilitation of water opportunities are illustrated by an integrated } \\
\text { phytoremediation system at Murdock, Nebraska, USA. }\end{array}$ & ANL, 2008. \\
\hline & & Potential for waste water treatment is illustrated by various rhizofiltration approaches. & Pivetz, 2001. \\
\hline & & Phytoremediation-based water treatment systems in Sweden. & Dimitriou and Aronsson, 2005. \\
\hline
\end{tabular}




\begin{tabular}{|c|c|c|c|}
\hline \multirow[t]{3}{*}{$\begin{array}{l}\text { Provision of } \\
\text { Green Space }\end{array}$} & $\begin{array}{l}\text { Enhancing } \\
\text { ecosystem } \\
\text { services }\end{array}$ & $\begin{array}{l}\text { Potential for phytoremediation in enhancing ecosystem services is illustrated by the } \\
\text { integrated phytoremediation treatment system at Murdock, Nebraska, USA, which } \\
\text { utilises co-planting of trees for phytovolatilisation with native prairie grasses and } \\
\text { wildflowers. }\end{array}$ & ANL, 2008. \\
\hline & & $\begin{array}{l}\text { Potential for phytoremediation in enhancing ecosystem services is illustrated by the } \\
\text { vegetated landfill cover at the BASF Rensselaer Landfill, NY, USA, with } \\
\text { phytoremediation planting designed to maximize ecological value, providing wildlife } \\
\text { habitat. }\end{array}$ & Kennen and Kirkwood, 2015. \\
\hline & $\begin{array}{l}\text { Enhancing } \\
\text { local } \\
\text { environment }\end{array}$ & $\begin{array}{l}\text { Potential for local environment enhancement is illustrated in Cundy et al., (2013) for } \\
\text { the Betteshanger site, SE England, where GRO application was part of a regeneration } \\
\text { initiative to develop a country park involving provision for walking, cycling, horse- } \\
\text { riding and wildlife observation. }\end{array}$ & Cundy et al., 2013; GREENLAND. \\
\hline \multirow{4}{*}{$\begin{array}{l}\text { Mitigation of } \\
\text { Human } \\
\text { Induced } \\
\text { Climate Change } \\
\text { (global } \\
\text { warming) }\end{array}$} & $\begin{array}{l}\text { Renewable } \\
\text { energy } \\
\text { generation }\end{array}$ & $\begin{array}{l}\text { A number of projects and field applications have shown the potential of } \\
\text { phytoremediation to generate usable biomass. }\end{array}$ & $\begin{array}{l}\text { Delplanque et al., 2013; Van Slycken et al., } \\
\text { 2013b; Cundy et al., 2013; Marchand et al., } \\
\text { 2015; GREENLAND. }\end{array}$ \\
\hline & $\begin{array}{l}\text { Renewable } \\
\text { material } \\
\text { generation }\end{array}$ & $\begin{array}{l}\text { Usable biomass production from phytoremediation approaches is shown in the listed } \\
\text { case studies. }\end{array}$ & $\begin{array}{l}\text { Delplanque et al., 2013; Witters et al., 2012; } \\
\text { Cundy et al., 2013; Gonsalvesh et al., 2016; } \\
\text { GREENLAND. }\end{array}$ \\
\hline & & $\begin{array}{l}\text { Usable biomass production from phytoremediation for metal recovery with biomass } \\
\text { reuse. }\end{array}$ & Anderson et al., 1999; Escande et al., 2015. \\
\hline & $\begin{array}{l}\text { Greenhouse } \\
\text { gas } \\
\text { mitigation }\end{array}$ & $\begin{array}{l}\text { Carbon abatement potential for a willow, maize and rapeseed-planted } \\
\text { phytoremediation site at Lommel, Belgium. }\end{array}$ & Witters et al., 2012. \\
\hline \multirow{4}{*}{$\begin{array}{l}\text { Socio- } \\
\text { Economic } \\
\text { Benefits }\end{array}$} & Amenity & Potential for amenity provision is illustrated in Cundy et al., (2013) for the & Cundy et al., 2013; GREENLAND. \\
\hline & & Betteshanger site, SE England, where GRO application was part of a regeneration & \\
\hline & & $\begin{array}{l}\text { initiative to develop a country park involving provision for walking, cycling, horse- } \\
\text { riding and wildlife observation. }\end{array}$ & \\
\hline & & $\begin{array}{l}\text { Potential for amenity provision is illustrated by the vegetated landfill cover at the BASF } \\
\text { Rensselaer Landfill, NY, USA, which contains an environmental education centre, } \\
\text { walking trails and an amphitheatre. }\end{array}$ & Kennen and Kirkwood, 2015. \\
\hline
\end{tabular}


Economic assets
Economic development opportunities are illustrated in Cundy et al., (2013) for the Betteshanger site, SE England, where GRO application was part of a regeneration initiative to develop a country park involving provision for walking, cycling, horseriding and wildlife observation.

Use of biomass options to leverage re-use of economically marginal land is evaluated by the REJUVENATE project.
Cundy et al., 2013; GREENLAND.

Andersson-Sköld et al., 2013.

\section{B. Amendment Addition}

\begin{tabular}{ll}
\hline General benefit & \\
\hline Risk Mitigation & $\begin{array}{l}\text { Biosphere } \\
\text { (including human }\end{array}$ \\
of & health) \\
Contaminated & \\
Land and & \\
Groundwater &
\end{tabular}

Water Resources (hydrosphere)

Soil Fertility

Improvement

ertility

Soil Structure

Composted organic wastes are applied to improve soil structure and plant biomass yield.

Compost can function as, e.g., soil conditioner, topsoil improver and mulch to improve plant growth and support soft re-use of sites.

Case Studies / citations

A number of studies examine the effects of compost on contaminant bioavailability.

Risk mitigation using carbon amendments (activated carbon, bone char and biochar), which impact the bioavailability of contaminants in soils.

The effectiveness of several amendments (limestone, red mud, and furnace slag) on availability of metal(loid)s, microbial activities, and phytoavailability of soil metals is evaluated.

The effectiveness of three different brownfield soils amended with green waste compost or biochar is examined in the context of increasing dissolved carbon concentrations in soil pore water and reducing As leaching to groundwater. The effects of a range of biochar products and chars amendment on heavy metal immobilization are examined with respect to water resource protection. A range of amendments such as lime, furnace slag, compost and red mud are applied at contaminated sites to generate improvements in soil fertility.

The effectiveness of biochar as a sorbent in removing metal(loid)s ( $\mathrm{Pb}, \mathrm{Cd}, \mathrm{Cu}$,

\begin{tabular}{ll}
\hline Water & Water resource \\
Resource & efficiency and \\
Improvement & quality
\end{tabular}

$\mathrm{Zn}, \mathrm{As}$ ) and U(VI) from groundwater and aqueous solutions is tested in various case studies.
CL:AIRE 2008; Tandy et al., 2008.

Denyes et al., 2013; Chen et al., 2006; Jones et al., 2016.

Lee et al., 2009; Gray et al., 2006; Marschner et al., 2010, 2011; Bert et al., 2012b.

Hartley et al., 2009.

Uchimiy et al., 2010 ; HOMBRE, 2014; Yang et al., 2016.

Lord et al., 2010; Gandolfi et al., 2010; Lee et

al., 2009; Bert el al. 2012b; Dadrasnia and

Agamuthu, 2013; Lagomarsino et al., 2011;

Xiong et al., 2015; WRAP (various refs); Jones et al., 2016.

Lord et al., 2010; CL:AIRE, 2008; TWIRLS.

WRAP, 2012; ECL and CL:AIRE, 2006.

Hartley et al., 2009; Kumar, 2011; Xu et al., 2013; Liang et al., 2014. 


\begin{tabular}{|c|c|c|c|}
\hline \multirow[t]{2}{*}{$\begin{array}{l}\text { Provision of } \\
\text { Green Space }\end{array}$} & $\begin{array}{l}\text { Enhancing } \\
\text { ecosystem services }\end{array}$ & $\begin{array}{l}\text { Services provided by green space and soft re-use strategies involving } \\
\text { amendment addition (such as wildlife habitat protection, regional trail links and } \\
\text { renewable energy production) are outlined. }\end{array}$ & LfULG, 2008; Lord, 2010; USEPA, 2010. \\
\hline & $\begin{array}{l}\text { Enhancing local } \\
\text { environment }\end{array}$ & $\begin{array}{l}\text { Rehabilitated sites (open spaces, parks, woodland and wildlife habitat) generate } \\
\text { a range of enhancements including amenity trails, air quality and water quality } \\
\text { improvement. }\end{array}$ & LRUG; USEPA, 2010. \\
\hline \multirow{3}{*}{$\begin{array}{l}\text { Mitigation of } \\
\text { Human } \\
\text { Induced } \\
\text { Climate Change } \\
\text { (global } \\
\text { warming) }\end{array}$} & $\begin{array}{l}\text { Renewable energy } \\
\text { generation }\end{array}$ & $\begin{array}{l}\text { Generation of energy crops (sunflower, miscanthus and SRC willow) and } \\
\text { renewable materials on brownfield land following amendment-based strategies. }\end{array}$ & $\begin{array}{l}\text { ECL and CL:AIRE, 2006; WRAP, 2007; Hartley } \\
\text { et al., 2009; Kolbas et al., 2011; Qantas et al., } \\
\text { 2013; HOMBRE, } 2014 .\end{array}$ \\
\hline & $\begin{array}{l}\text { Renewable material } \\
\text { generation }\end{array}$ & $\begin{array}{l}\text { Promoting material use and reusing waste are considered as environmental } \\
\text { indicators of sustainability in a Cluster project. }\end{array}$ & CL:AIRE, 2012. \\
\hline & $\begin{array}{l}\text { Greenhouse gas } \\
\text { mitigation }\end{array}$ & $\begin{array}{l}\text { Carbon storage and sequestration benefits are determined following soil } \\
\text { amendment with green waste compost and biochar. }\end{array}$ & Beesley, 2012; HOMBRE, 2014. \\
\hline \multirow{3}{*}{$\begin{array}{l}\text { Socio- } \\
\text { Economic } \\
\text { Benefits }\end{array}$} & Amenity & $\begin{array}{l}\text { Potential for amenity provision along with other benefits by plant growth or } \\
\text { woodland are examined at various sites. }\end{array}$ & $\begin{array}{l}\text { Palmer and Davies, 2008; HOMBRE, 2013; } \\
\text { LRUG. }\end{array}$ \\
\hline & & $\begin{array}{l}\text { Four cases are summarized to show that compost can help to restore wetlands, } \\
\text { forests and revitalize habitats by providing an excellent growing medium for } \\
\text { young seedlings. }\end{array}$ & USEPA and SWER, 1997. \\
\hline & Economic assets & $\begin{array}{l}\text { The possibility of income generation, employment opportunities and other } \\
\text { economic return in land regeneration are qualified in several case studies. }\end{array}$ & $\begin{array}{l}\text { Paulson et al., 2003; Wilczek, 2004; WRAP, } \\
\text { 2009; LRUG. }\end{array}$ \\
\hline
\end{tabular}


Figure 1: Example risk management strategy using GROs customised along contaminant linkages. Outfacing arrows link to illustrative wider environmental, economic and societal benefits that may be realised from GRO application. After Cundy et al., (2013) and www.greenland-project.eu. See Section 4 for discussion.

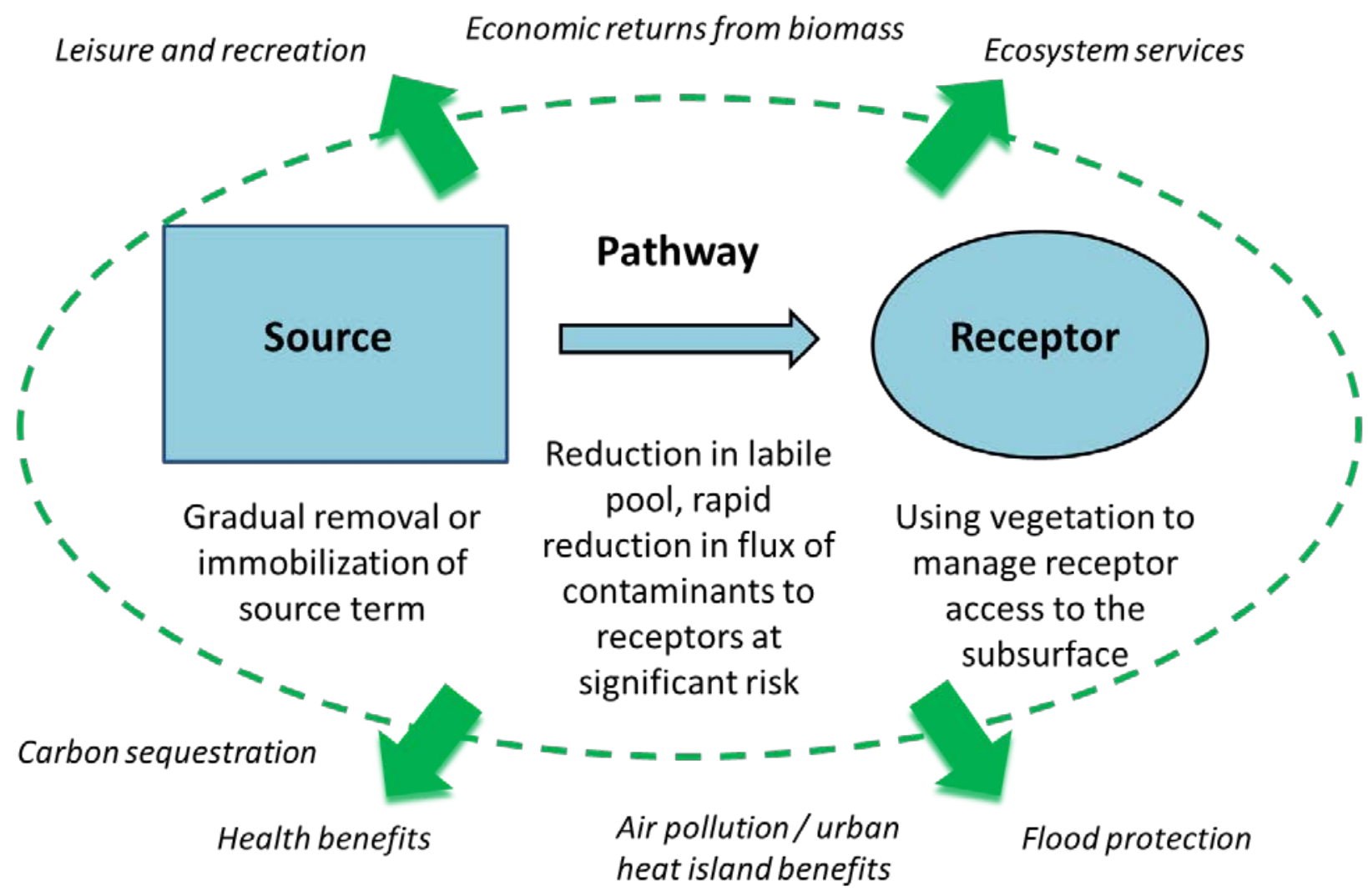

